\title{
Article
}

\section{The Cost-Benefits and Risks of Using Raffia Made of Biodegradable Polymers: The Case of Pepper and Tomato Production in Greenhouses}

\author{
Josefa López-Marín ${ }^{1, * \mathbb{C}}$, Amparo Gálvez ${ }^{1}{ }^{(\mathbb{C}}$, Francisco M. del Amor ${ }^{1}\left(\mathbb{D}\right.$, Mari Carmen Piñero ${ }^{1}(\mathbb{D}$ \\ and Jose M. Brotons-Martínez ${ }^{2}$ (D)
}

check for

updates

Citation: López-Marín, J.; Gálvez, A.; del Amor, F.M.; Piñero, M.C.;

Brotons-Martínez, J.M. The CostBenefits and Risks of Using Raffia Made of Biodegradable Polymers: The Case of Pepper and Tomato Production in Greenhouses.

Horticulturae 2022, 8, 133. https:// doi.org/10.3390/horticulturae8020133

Academic Editors: Zhengfei Guan and Johan Desaeger

Received: 20 December 2021

Accepted: 29 January 2022

Published: 1 February 2022

Publisher's Note: MDPI stays neutral with regard to jurisdictional claims in published maps and institutional affiliations.

Copyright: (c) 2022 by the authors. Licensee MDPI, Basel, Switzerland. This article is an open access article distributed under the terms and conditions of the Creative Commons Attribution (CC BY) license (https:// creativecommons.org/licenses/by/ $4.0 /)$.
1 Department of Crop Production and Agri-Technology, Instituto Murciano de Investigación y Desarrollo Agrario y Medioambiental, 30150 Murcia, Spain; amparo.galvez@carm.es (A.G.);

franciscom.delamor@carm.es (F.M.d.A.); mariac.pinero2@carm.es (M.C.P.)

2 Department of Economic and Financial Studies, Miguel Hernández University, Elche, 03202 Alicante, Spain; jm.brotons@umh.es

* Correspondence: josefa.lopez38@carm.es

\begin{abstract}
The use of plastics in agriculture has increased food production and reduced irrigation, pesticides, and pests. However, according to the Food and Agriculture Organization of the United Nations (FAO), "disastrous" use has occurred, as agricultural soils are being contaminated and have begun to threaten food security, peoples' health, and the environment. One of the most challenging plastic wastes that must be removed from plants, and instead recycled, is the raffia used to tutor crops. This work studied the economic risk of introducing raffia made from a biodegradable polymer in greenhouse pepper and tomato crops. An expert survey was carried out to analyze the evolution of breaks throughout the season of four biodegradable raffias: cellulose, cellulose + kraft paper, compostable biopolymer, and jute-rayon, comparing them with a polypropylene control for two years (2019-2020) in pepper and tomato crops. Fuzzy logic-ordered weighted averages (OWA) were used to treat and aggregate this information. Income, costs, and the risk of biodegradable raffia breakage were studied. The results show that the material that performed the best was the biopolymer in the two crops studied, as it presented a much lower risk of breakage. The breaks in tomatoes were higher than those produced in pepper for each material. For the biopolymer, the internal rates of return (3.49\% in tomatoes and $8.14 \%$ in peppers) and the recovery period (18.50 and 13.45 years for tomato and pepper crops, respectively) were very similar to those of polypropylene.
\end{abstract}

Keywords: yarn; plastic; eco-friendly; sustainably; fuzzy

\section{Introduction}

Almost a million tons of polymeric materials are generated, per year, by intensive horticulture, which is causing a large problem [1]. The horticultural production system uses a large number of synthetic materials, such as polyethylene (PE) and polypropylene (PP), which are utilized for tunnels, greenhouses, nets for crop protection and shading, soil mulching, solarization films, films for silage, seedling pots, and ropes and clips to hold plants, among others. This generates large amounts of non-biodegradable plastic waste [2], which is difficult for farmers to manage.

One of the most difficult-to-recycle, or separate from residues, is raffia (non-biodegradable polypropylene threads), which is used to keep the plant straight and to improve the production of the crops and the quality of the fruits. Raffia is a synthetic fiber yarn, obtained by the extrusion of polyolefins (PE and PP) [3].

According to the trellising technique, the plant will be led into a vertical and/or horizontal direction with raffia fiber used to guide wires, structural elements of the greenhouse, or in open air crops. This cultivation technique, among others, is used in important crops, such as tomato and pepper $[4,5]$. 
In pepper, two types of tutoring are used: conventional/bundle tutoring, and Dutch pruning trellising, with the latter utilized when Dutch pruning is performed. This type of pruning is not common in Southeastern Spain, given that its elevated cost is not significantly reflected in better pepper sales. Therefore, the present study will focus on horizontal tutoring. Pepper is tutored horizontally with longitudinal threads at a height of about 20-25 cm, joining each of the parallel lines with a transversal thread, so that the plant does not fall sideways [6]. The structure of the threads is tied to iron nails that are about $1.3 \mathrm{~m}$ in height, placed at the ends. Five to six rows are tutored in height. Tomatoes use a hook-and-loop trellising system, which consists on holding the stem of the plant with a raffia thread or string (polypropylene or similar), so that one end of the thread is placed on the base of the plant (tied, knotted, or held with clips), and the other end is held to a horizontal mesh of wires placed in the interior of the greenhouse ("grating"), or to a hook [4].

However, the polypropylene threads that are traditionally used for these crops remain in the plants, and their removal is costly, so growers have difficulties in managing the plants and cannot use them for green manure or compost production, as raffia waste remains in the plants.

To mitigate these problems, other types of raffia have appeared, which are made from compostable/biodegradable materials [7], which could ease the composting of plant residues and, therefore, improve the soil conditions while increasing circularity and sustainability in greenhouses. To achieve the objectives of a circular bioeconomy, the good practices of sustainable management and the valorization of agricultural waste are necessary [8].

The biodegradable raffias that have appeared in the past few years have different natures, and we, therefore, obtained jute (from Tiliaceae plants), rattan (from species found in the genus Calamus and Daemonorops), cellulose polymers, and biodegradable polymers (from PLA and thermoplastic starch (TPS)) mixes, etc. [7,9]).

Not all materials have the same benefits and properties as PP, and it is necessary to study what risk the farmer could assume in each of the crops made. In agriculture, the risk is introduced using a discount rate higher than the risk-free rate [10,11]. However, recent studies in agriculture used the decoupled net present value, based on the incorporation, into the study, all the risks inherent to the crop [12]. Therefore, an in-depth analysis of all the existing risks in a crop is required.

In this work, we focus on studying the economic viability of using different types of biodegradable/compostable raffia in greenhouse tomato and pepper crops and the risks that the farmer can expect without suffering losses in each of these crops. The risk of the breakage of the biodegradable raffia and the consequent loss in production is introduced as an additional cost. Therefore, the hypothesis that we put forward in this study is that the use of biodegradable raffia will allow for a positive annualized yield.

Consequently, this work aimed to estimate the risk of the breakage of biodegradable raffia among farmers who use this type of raffia to estimate the percentage of weekly breakages. Different aggregators were proposed to improve the quality of the results obtained. Finally, the annualized yield of the crops with the different materials used, the recovery period, and the current net value were obtained.

\section{Materials and Methods}

\subsection{Materials}

The study lasted two years, and data from 10 growers, including five cultivated peppers and five tomatoes, were collected. In all the cases, the greenhouses were Almeriatype (parral), covered with thermal polyethylene. All the peppers were Lamuyo, and the tomatoes were long-life. The planting of tomatoes was performed at weeks 48 and 50, and for sweet peppers, 51 and 1, in the years studied (2018-2020). The original soil type was clay loam soil, with a $\mathrm{pH}$ of 7.2 to 7.7 and the electrical conductivity of saturated soil extract was 5.2-5.7 $\mathrm{dSm}^{-1}$. Irrigation was applied based on estimations of the weekly crop 
evapotranspiration. The plant density was 2.5 plants $/ \mathrm{m}^{2}$ and the growing techniques were the usual techniques for greenhouse peppers and tomatoes in Spain.

The experimental design was a randomized complete block with four replications and five types of raffia. The raffia materials utilized were four types of biodegradable materials: cellulose, cellulose + kraft paper, a compostable biopolymer, and jute-rayon, which were compared with the conventional material, polypropylene (Table 1). The pepper plants were tutored by a conventional or bundle system horizontally, with longitudinal threads at a height of about $20-25 \mathrm{~cm}$, joining each of the parallel lines with a transversal thread. Five to six rows were tutored in height. A hook-and-loop trellising system was used for the tomatoes. The stem of the plant was held with a raffia thread at the base of the plant (tied, knotted, or held with clips), and the other end was held to a horizontal mesh of wires placed in the interior of the greenhouse ("grating").

Table 1. Raffias utilized and tensile strength at break.

\begin{tabular}{lcc}
\hline & \multicolumn{2}{c}{ Tensile Strength at Break (kg) } \\
\hline & Tomato & Pepper \\
Polypropylene & 47 & 47 \\
Cellulose & 35 & 20 \\
Cellulose + kraft paper & 20 & 20 \\
Compostable biopolymer & 35 & 27 \\
Jute-rayon & 28 & 28 \\
\hline
\end{tabular}

The air temperature inside the greenhouse was monitored during the growing cycle using a Hobo U12 temperature data logger (Onset, MA, USA) (Table 2).

Table 2. Average air temperatures $\left({ }^{\circ} \mathrm{C}\right)$ in the five greenhouses (G1 to G5).

\begin{tabular}{lcc}
\hline & Tomato & Pepper \\
\hline G1 & 30.1 & 29.5 \\
G2 & 29.0 & 28.5 \\
G3 & 28.5 & 29.1 \\
G4 & 29.2 & 28.3 \\
G5 & 28.1 & 27.5 \\
\hline
\end{tabular}

The tomatoes and sweet peppers were harvested at their optimum collection time, weighed, and then classified as marketable and nonmarketable (sun-affected, tissue rot, etc.). The total (marketable + nonmarketable) fruit was determined and expressed on a per hectare basis [13,14]. Between 10 and 12 harvests were made for tomatoes, and between 8 and 10 for peppers, in all the alternatives analyzed.

\subsection{Economic Study}

A cost-benefit analysis was carried out to study the risk of using biodegradable raffia $[15,16]$. The annual crop income was obtained as the average of the two seasons, and as a product of the weekly production by the average weekly price in the last 10 years [17]. Each seasonal production was valued using these average prices to avoid changes in income due to annual fluctuations in prices.

The breakage risk was introduced, as it lowers income, and it was estimated based on the experiences of the farmers in the area. For this, an expert group was asked to provide their opinion on the breaks that occurred when using the different biodegradable raffias. In particular, five farmers were interviewed for each of the four types of biodegradable raffia they had used (cellulose, cellulose + kraft paper, biopolymer, compostable, or jute-rayon) to evaluate the possibilities of breakage during the season. Given that such information inherently carries high doses of subjectivity, fuzzy mathematics introduced by Zadeh [18] was used. Such opinions were described as shown in triangular fuzzy numbers $\widetilde{a}=(\alpha, \beta, \gamma)$, 
where $\beta$ is the most possible value. However, that value can change from a minimum value $(\alpha)$ to a maximum value $(\gamma)$. The experts' group periodically gave their opinions on the percentage of tomato and pepper raffia breakages throughout the season. The survey was carried out every three weeks $(15,18,21,24$, and 27 , from the plantation) in tomatoes, and every four $(18,22,26,30$, and 34$)$ in peppers, to obtain the weekly break estimation. The aggregation was carried out in four different ways:

1. The arithmetic mean. Each extreme of the added values were obtained as the average of the corresponding extremes provided by the experts,

$$
\widetilde{A}^{1}=\left(\frac{1}{n} \sum_{i=1}^{n} \alpha_{i}, \frac{1}{n} \sum_{i=1}^{n} \beta_{i}, \frac{1}{n} \sum_{i=1}^{n} \gamma_{i}\right)
$$

2. Assigning a confidence level $p_{i}^{*}$ to each expert between 1 and 10 . The probability assigned to each expert will be the result of normalizing the opinion of the $\mathrm{n}$ experts, $p_{i}=p_{i}^{*} / \sum_{i=1}^{n} p_{i}^{*}$, obtaining the second aggregation,

$$
\widetilde{A}^{2}=\left(\sum_{i=1}^{n} p_{i} \alpha_{i}, \sum_{i=1}^{n} p_{i} \beta_{i}, \sum_{i=1}^{n} p_{i} \gamma_{i}\right)
$$

3. Adding the opinions based on the optimism or pessimism level. For this, the ordered weighted average (OWA) [19] was used. An OWA is defined as a mapping of a dimension $n, F: R^{n} \rightarrow R$ that has an associated weighting vector, $W$, of dimension $n$, $W^{T}=\left[w_{1}, w_{2}, \ldots w_{n}\right]$, such that $w_{j} \in[0,1]$ and $\sum_{j=1}^{n} w_{j}=1$, with

$$
\mathrm{OWA}\left(a_{1}, a_{2}, \ldots a_{n}\right)=\sum_{j=1}^{n} w_{j} \cdot b_{j}
$$

where $b_{j}$ is the jth largest of the $a_{i}$.

By using OWAs, the third aggregation of the experts' opinions were obtained,

$$
\widetilde{A}^{3}=\left(O W A\left(\alpha_{1}, \ldots, \alpha_{n}\right), O W A\left(\beta_{1}, \ldots, \beta_{n}\right), O W A\left(\gamma_{1}, \ldots, \gamma_{n}\right)\right)
$$

4. Using ascending ordered weighting averages (AOWA) [20], which are defined as a mapping of dimension $n, F: R^{n} \rightarrow R$, that has an associated weighting vector, $W$, of dimension $n, W^{T}=\left[w_{1}, w_{2}, \ldots w_{n}\right]$, such that $w_{j} \in[0,1]$ and $\sum_{j=1}^{n} w_{j}=1$, with

$$
\operatorname{AOWA}\left(a_{1}, a_{2}, \ldots a_{n}\right)=\sum_{j=1}^{n} w_{j} \cdot b_{j}
$$

where $b_{j}$ is the jth smallest of the $a_{i}$.

By using the AOWAs, we obtained the fourth aggregation of expert opinions (farmers),

$$
\widetilde{A}^{4}=\left(\operatorname{AOW} A\left(\alpha_{1}, \ldots, \alpha_{n}\right), \operatorname{AOWA}\left(\beta_{1}, \ldots, \beta_{n}\right), \operatorname{AOW} A\left(\gamma_{1}, \ldots, \gamma_{n}\right)\right)
$$

The OWAs assign the first weight to the expert who provides a higher value, the second weight to the expert who provides the second-highest opinion, etc. The AOWAs carry out this assignment in the opposite manner, assigning the first weight to the lowest value (regardless of the expert who provides it), the second to the second smallest opinion, etc. This process was repeated for each of the five treatments of the two crops. The experts were not always the same, as not everyone had used all the materials. 
The mean of the three aggregations allowed the obtainment of the triangular fuzzy number mean value. Next, the uncertainty inherent in said fuzzy number was eliminated by defuzzifying its value using the center of gravity method. Thus, if the added value is $\widetilde{A}=\left(\alpha^{*}, \beta^{*}, \gamma^{*}\right)$, the corresponding defuzzified value is $A=\left(\alpha^{*}+2 \beta^{*}+\gamma^{*}\right) / 4$.

In this way, an estimation of the accumulated percentage of breakages was obtained for each week the survey was conducted. Each period's breakage was the difference between two consecutive manifestations. The economic valuation was obtained by multiplying three factors: the percentage of breakages reached; the production, pending harvesting, at the beginning of the period; and the average price during that week. The production, pending harvesting, was obtained as the weekly average of the two years under study. The net income was obtained by reducing the income from the risk calculated in the previous section.

For the analysis of productivity, the following indicators were used: productive efficiency (the quotient between production obtained, minus the calculated risk and the kilograms of raffia used), productivity (the quotient of income reduced by the risk of breakage and the kilograms of raffia consumed), and economic efficiency (the quotient between the net benefit, considering the risk of breakage, as well as the removal costs, the cost of the raffia, and the kilograms of raffia used).

The net present value (NPV) of each alternative in the two crops was obtained by updating the annual net cash flows, $F_{i}$, corresponding to the initial investment and benefits during $\mathbf{N}$ years of useful life assigned to the greenhouse structure [21,22]:

$$
N P V=\sum_{i=1}^{N} F_{i}(1+i)^{-n}
$$

Next, the result was annualized $(A V)$ to obtain the annual incidence of NPV obtained in (6):

$$
A V=N P V \frac{i}{1-(1+i)^{-n}}
$$

The internal rate of return (IRR) $(r)$ was obtained by equating the NPV to zero:

$$
0=\sum_{i=1}^{N} F_{i}(1+r)^{-n}
$$

Finally, the payback $(P B)$ was calculated by dividing the sum of all investments made during the useful life of the greenhouse $\left(I_{s}\right)$ by the average annual profit $(F)[21,22]$ :

$$
P B=\frac{1}{F} \sum_{s=1}^{N} I_{s}
$$

The maximum price of the raffia $(P R)$, so that the business did not suffer a loss, was obtained by dividing the company's margin by the volume of raffia used $(R)$. The margin was the difference between the income (production, $V$, multiplied by its price, $p$ ) and the costs, not including those of the raffia. Cost were the sum of fixed costs, $F C$ and variable costs, $C_{r}$ :

$$
P R=\frac{V p-\left(F C+C_{r} V\right)}{R}
$$

\section{Results and Discussion}

\subsection{Incomes}

Figure 1 shows the evolution of prices during the harvest weeks from mid-April to the end of July. The data corresponds to the average prices in the latest ten years, obtained from the Ministry of Agriculture of the Community of Murcia [17]. As can be observed, in both crops, prices fell rapidly in the first weeks and stabilized later, with a slight rebound at the 
end of the season. The risk of temporary and permanent price declines has been analyzed in other studies [12], and a fuzzy model has been developed for its evaluation [23].

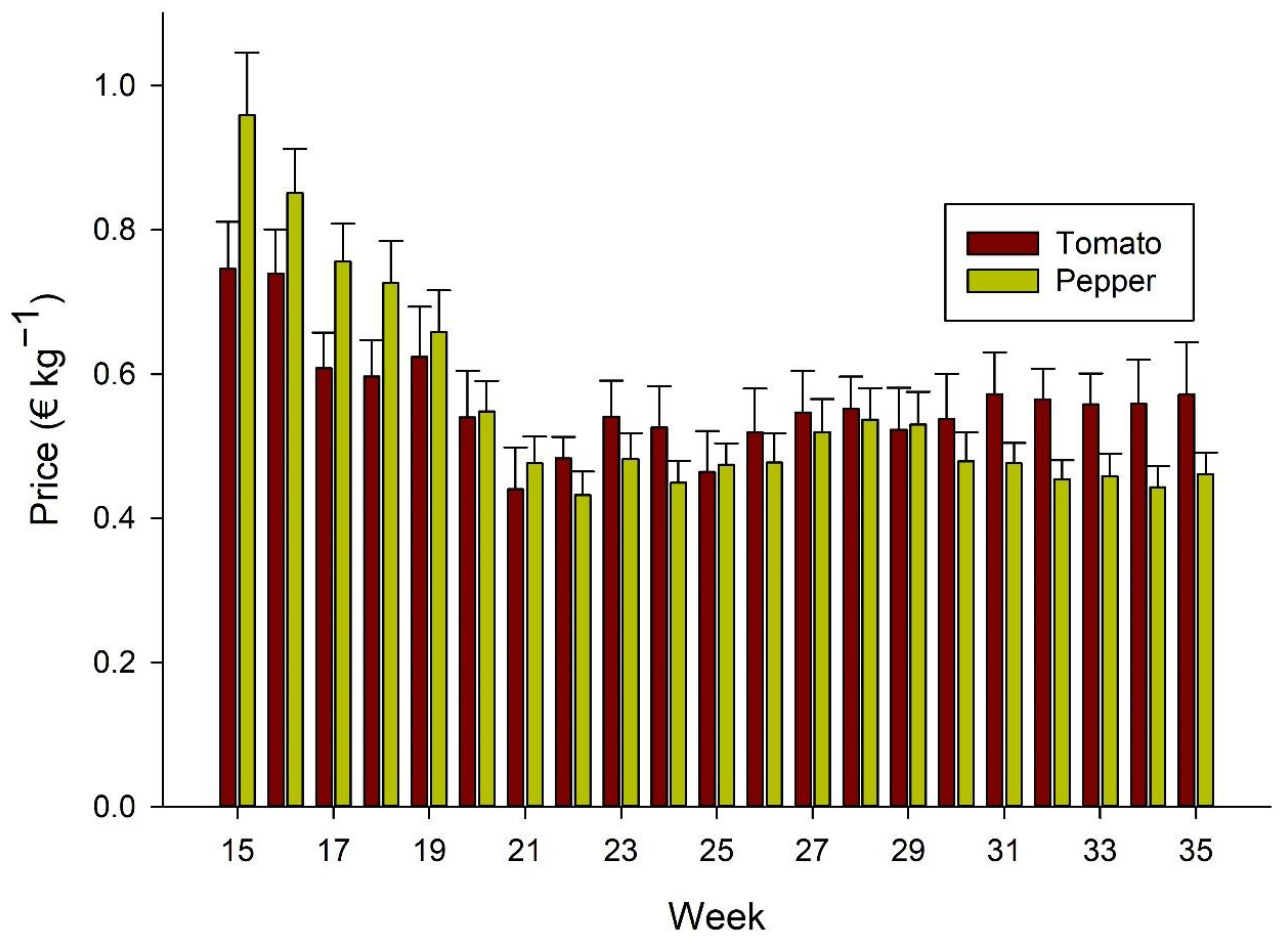

Figure 1. Prices (weekly mean price \pm standard error).

A cost-benefit study was carried out to analyze the profitability of each crop [24-26]. Figure 2 shows the production and the average weekly income of the tests carried out for peppers and tomatoes in 2019 and 2020. The production of each crop shows a large weekly dispersion, although in the annual aggregate, the difference between the two seasons was less than $1 \%$ of the average values. This is similar to results seen in other studies, such as Lopez-Marín et al. [5] for sweet peppers, or Lopez-Marin et al., in 2019, for tomatoes [27]. As observed, the income was lower for the similar levels of production at the end of the season, due to the decrease in prices (Figure 1).

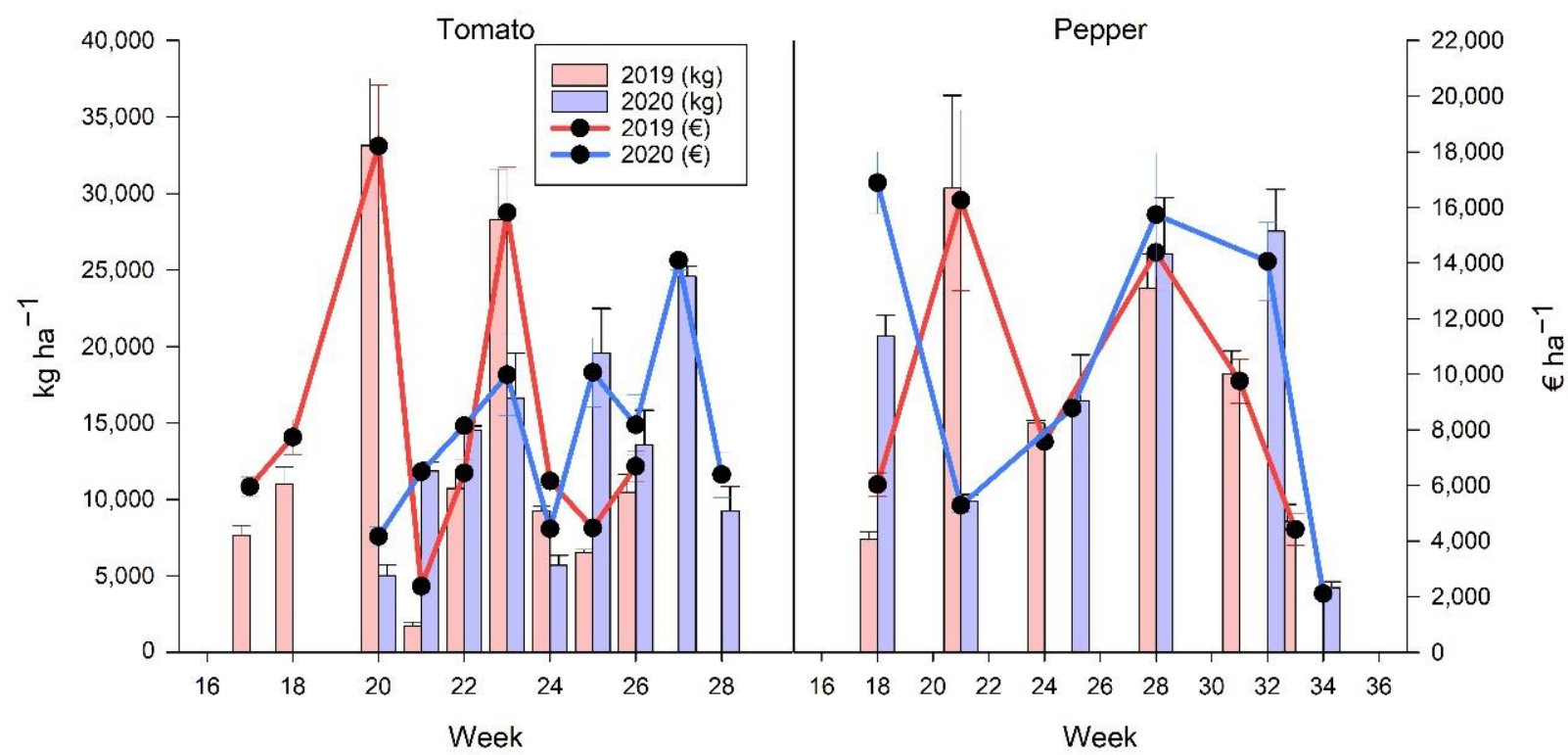

Figure 2. Production and income per hectare of pepper and tomato during the 2019 and 2020 seasons (average \pm standard error). 
Biodegradable raffia is manufactured so that it degrades over a short period [28]. The problem arises when they fracture or break before the end of the season, as the fall of that particular plant, or of nearby plants, can lead to mechanical damage that, in most cases, is irreparable [29]. There are numerous international and local policies, regulations, and strategies that promote the use of biodegradable and compostable materials in agriculture [30,31]. Unfortunately, there are few studies on the damage caused or the risks involved in the breakage of these tutors. Due to the uncertainty brought on by the lack of knowledge about these biodegradable materials, it is crucial to know the risks that farmers can bear when integrating this environmentally sustainable technology into their crops. That is why, in this work, the yields obtained with the conventional raffia material were studied. Thus, starting with the weekly production (Figure 2), the possible losses were obtained according to the point in time in the season in which we were. For example, at week $18,5499.83 \mathrm{~kg}$ of tomatoes were harvested, at week $20,19,072.03 \mathrm{~kg}$, etc., with a total of $119,730.00 \mathrm{~kg}$. If all the raffia were broken during that week, the loss would have been $115,917.91 \mathrm{~kg}$, which is $96.82 \%$ of the average production of the two years (Table 3 ).

Table 3. Weekly harvest and pending production, on average (2019-2020), of tomatoes and peppers.

\begin{tabular}{|c|c|c|c|c|c|c|c|}
\hline \multirow[b]{2}{*}{ Week } & \multicolumn{3}{|c|}{ Tomatoes } & \multicolumn{3}{|c|}{ Peppers } & \multirow[b]{2}{*}{$\begin{array}{c}\text { Pending } \\
\text { Production }(\%)\end{array}$} \\
\hline & Harvest (kg) & $\begin{array}{c}\text { Pending } \\
\text { Production (kg) }\end{array}$ & $\begin{array}{c}\text { Pending } \\
\text { Production (\%) }\end{array}$ & Week & Harvest (kg) & $\begin{array}{c}\text { Pending } \\
\text { Production (kg) }\end{array}$ & \\
\hline 17 & 3812.09 & $119,730.00$ & 100.00 & 18 & $15,780.00$ & $117,065.44$ & 100.00 \\
\hline 18 & 5499.83 & $115,917.91$ & 96.82 & 21 & $22,625.00$ & $101,285.44$ & 86.52 \\
\hline 20 & $19,072.03$ & $110,418.08$ & 92.22 & 24 & 8431.00 & $78,660.44$ & 67.19 \\
\hline 21 & 6793.40 & $91,346.05$ & 76.29 & 25 & 9258.33 & $70,229.44$ & 59.99 \\
\hline 22 & $12,612.27$ & $84,552.65$ & 70.62 & 28 & $28,044.46$ & $60,971.10$ & 52.08 \\
\hline 23 & $22,465.32$ & $71,940.38$ & 60.09 & 31 & $10,244.32$ & $32,926.65$ & 28.13 \\
\hline 24 & 7471.11 & $49,475.06$ & 41.32 & 32 & $15,483.33$ & $22,682.33$ & 19.38 \\
\hline 25 & $13,066.25$ & $42,003.95$ & 35.08 & 33 & 4820.00 & 7199.00 & 6.15 \\
\hline 26 & $12,018.90$ & $28,937.69$ & 24.17 & 34 & 2379.00 & 2379.00 & 2.03 \\
\hline 27 & $12,290.95$ & $16,918.80$ & 14.13 & Total & $117,065.44$ & & \\
\hline 28 & 4627.84 & 4627.84 & 3.87 & & & & \\
\hline Total & $119,730.00$ & & & & & & \\
\hline
\end{tabular}

Not all the raffia broke in one week, so the farmer's survey was carried out. Tables 4 and 5 show their opinions for each of the treatments in each week under study. Thus, the first column shows the expert number, the second their confidence level (from 1 to 10), and the third to the seventh, the experts' opinions on the breakages. These views are displayed in triplet form in a way similar to that used in other works [32]. For example, for tomatoes in week 21 during the cellulose treatment, expert 1 considered that the breaks ranged between $4 \%$ and $6 \%$, with the largest possible value being $5 \%$.

Table 4. Experts' opinions on the percentage of raffia breakage in tomatoes for each week, and the level of confidence of each expert. The opinion is expressed in triplets $(\alpha, \beta, \gamma)$, where $\alpha$, $\beta$, and $\gamma$, represent the lowest value, the most possible value, and the highest expected value, respectively.

\begin{tabular}{ccccccc}
\hline \multicolumn{7}{c}{ Cellulose } \\
\hline Expert & Confidence & $\mathbf{1 5}$ & $\mathbf{1 8}$ & $\mathbf{2 1}$ & $\mathbf{2 4}$ & $\mathbf{2 7}$ \\
\hline 1 & 7 & $\{0 ; 1 ; 1\}$ & $\{0 ; 3 ; 4\}$ & $\{4 ; 5 ; 6\}$ & $\{6 ; 8 ; 9\}$ & $\{7 ; 11 ; 14\}$ \\
2 & 4 & $\{0 ; 0 ; 1\}$ & $\{1 ; 1 ; 2\}$ & $\{2 ; 3 ; 5\}$ & $\{5 ; 7 ; 9\}$ & $\{9 ; 10 ; 12\}$ \\
3 & 3 & $\{0 ; 0 ; 0\}$ & $\{1 ; 2 ; 3\}$ & $\{3 ; 3 ; 4\}$ & $\{4 ; 6 ; 8\}$ & $\{6 ; 8 ; 10\}$ \\
4 & 8 & $\{0 ; 2 ; 3\}$ & $\{0 ; 3 ; 3\}$ & $\{4 ; 6 ; 6\}$ & $\{6 ; 7 ; 11\}$ & $\{7 ; 11 ; 13\}$ \\
5 & 7 & $\{0 ; 1 ; 2\}$ & $\{1 ; 2 ; 3\}$ & $\{3 ; 4 ; 5\}$ & $\{4 ; 5 ; 6\}$ & $\{5 ; 5 ; 7\}$ \\
\hline
\end{tabular}


Table 4. Cont.

\begin{tabular}{|c|c|c|c|c|c|c|}
\hline \multicolumn{7}{|c|}{ Cellulose + Kraft Paper } \\
\hline Expert & Confidence & 15 & 18 & 21 & 24 & 27 \\
\hline 1 & 4 & $\{0 ; 0 ; 1\}$ & $\{0 ; 1 ; 1\}$ & $\{2 ; 3 ; 4\}$ & $\{6 ; 7 ; 8\}$ & $\{7 ; 8 ; 11\}$ \\
\hline 2 & 10 & $\{0 ; 0 ; 1\}$ & $\{0 ; 0 ; 2\}$ & $\{1 ; 1 ; 3\}$ & $\{3 ; 4 ; 6\}$ & $\{6 ; 7 ; 8\}$ \\
\hline 3 & 9 & $\{0 ; 1 ; 1\}$ & $\{1 ; 2 ; 3\}$ & $\{2 ; 3 ; 4\}$ & $\{4 ; 4 ; 5\}$ & $\{4 ; 6 ; 7\}$ \\
\hline 4 & 5 & $\{0 ; 0 ; 1\}$ & $\{0 ; 1 ; 3\}$ & $\{2 ; 2 ; 3\}$ & $\{3 ; 5 ; 6\}$ & $\{7 ; 8 ; 10\}$ \\
\hline 5 & 3 & $\{0 ; 0 ; 2\}$ & $\{1 ; 1 ; 2\}$ & $\{1 ; 2 ; 3\}$ & $\{6 ; 7 ; 9\}$ & $\{7 ; 9 ; 11\}$ \\
\hline \multicolumn{7}{|c|}{ Compostable Biopolymer } \\
\hline Expert & Confidence & 15 & 18 & 21 & 24 & 27 \\
\hline 1 & 9 & $\{0 ; 0 ; 0\}$ & $\{0 ; 0 ; 1\}$ & $\{1 ; 1 ; 2\}$ & $\{2 ; 2 ; 4\}$ & $\{2 ; 3 ; 5\}$ \\
\hline 2 & 5 & $\{0 ; 0 ; 1\}$ & $\{0 ; 0 ; 1\}$ & $\{0 ; 0 ; 1\}$ & $\{0 ; 1 ; 1\}$ & $\{4 ; 5 ; 7\}$ \\
\hline 3 & 10 & $\{0 ; 0 ; 0\}$ & $\{1 ; 1 ; 1\}$ & $\{1 ; 1 ; 2\}$ & $\{2 ; 2 ; 3\}$ & $\{2 ; 3 ; 3\}$ \\
\hline 4 & 7 & $\{0 ; 0 ; 1\}$ & $\{0 ; 1 ; 1\}$ & $\{1 ; 2 ; 3\}$ & $\{2 ; 4 ; 4\}$ & $\{2 ; 3 ; 4\}$ \\
\hline 5 & 8 & $\{0 ; 0 ; 1\}$ & $\{1 ; 1 ; 2\}$ & $\{1 ; 2 ; 4\}$ & $\{3 ; 5 ; 7\}$ & $\{4 ; 6 ; 8\}$ \\
\hline \multicolumn{7}{|c|}{ Jute-Rayon } \\
\hline Expert & Confidence & 15 & 18 & 21 & 24 & 27 \\
\hline 1 & 10 & $\{0 ; 0 ; 1\}$ & $\{0 ; 1 ; 1\}$ & $\{0 ; 1 ; 1\}$ & $\{4 ; 5 ; 8\}$ & $\{7 ; 8 ; 10\}$ \\
\hline 2 & 6 & $\{0 ; 0 ; 1\}$ & $\{0 ; 0 ; 1\}$ & $\{1 ; 1 ; 3\}$ & $\{1 ; 3 ; 5\}$ & $\{3 ; 4 ; 5\}$ \\
\hline 3 & 9 & $\{0 ; 1 ; 2\}$ & $\{1 ; 2 ; 2\}$ & $\{1 ; 3 ; 4\}$ & $\{4 ; 5 ; 5\}$ & $\{6 ; 7 ; 7\}$ \\
\hline 4 & 5 & $\{0 ; 0 ; 1\}$ & $\{1 ; 3 ; 4\}$ & $\{1 ; 3 ; 4\}$ & $\{3 ; 5 ; 7\}$ & $\{4 ; 6 ; 8\}$ \\
\hline 5 & 3 & $\{1 ; 1 ; 2\}$ & $\{1 ; 2 ; 2\}$ & $\{3 ; 4 ; 7\}$ & $\{4 ; 6 ; 8\}$ & $\{7 ; 8 ; 9\}^{1}$ \\
\hline
\end{tabular}

${ }^{1}$ The polypropylene data is not presented due to it having $0 \%$ breakage in the surveys carried out.

Table 5. Experts' opinions on the percentage of breakage in the raffia in peppers for each week, and the level of confidence of each expert. The opinion is expressed in triplets $(\alpha, \beta, \gamma)$, where $\alpha, \beta$, and $\gamma$ represent the lowest value, the most possible value, and the highest expected value, respectively.

\begin{tabular}{|c|c|c|c|c|c|c|}
\hline \multicolumn{7}{|c|}{ Cellulose } \\
\hline Expert & Confidence & 18 & 22 & 26 & 30 & 34 \\
\hline 1 & 8 & $\{0 ; 0 ; 1\}$ & $\{0 ; 1 ; 1\}$ & $\{1 ; 1 ; 1\}$ & $\{2 ; 2 ; 3\}$ & $\{2 ; 5 ; 8\}$ \\
\hline 2 & 7 & $\{0 ; 0 ; 1\}$ & $\{0 ; 1 ; 2\}$ & $\{1 ; 1 ; 2\}$ & $\{1 ; 2 ; 4\}$ & $\{1 ; 3 ; 7\}$ \\
\hline 3 & 9 & $\{0 ; 0 ; 1\}$ & $\{0 ; 1 ; 2\}$ & $\{0 ; 1 ; 2\}$ & $\{1 ; 2 ; 5\}$ & $\{2 ; 3 ; 5\}$ \\
\hline 4 & 5 & $\{0 ; 0 ; 1\}$ & $\{0 ; 0 ; 1\}$ & $\{1 ; 2 ; 3\}$ & $\{2 ; 4 ; 6\}$ & $\{2 ; 5 ; 6\}$ \\
\hline 5 & 7 & $\{0 ; 0 ; 1\}$ & $\{0 ; 1 ; 2\}$ & $\{0 ; 1 ; 4\}$ & $\{1 ; 4 ; 7\}$ & $\{2 ; 4 ; 9\}$ \\
\hline \multicolumn{7}{|c|}{ Cellulose + Kraft Paper } \\
\hline Expert & Confidence & 18 & 22 & 26 & 30 & 34 \\
\hline 1 & 3 & $\{0 ; 0 ; 1\}$ & $\{0 ; 1 ; 3\}$ & $\{1 ; 2 ; 4\}$ & $\{1 ; 4 ; 6\}$ & $\{1 ; 5 ; 8\}$ \\
\hline 2 & 9 & $\{0 ; 0 ; 0\}$ & $\{0 ; 0 ; 2\}$ & $\{1 ; 1 ; 2\}$ & $\{1 ; 2 ; 4\}$ & $\{1 ; 2 ; 5\}$ \\
\hline 3 & 3 & $\{0 ; 1 ; 1\}$ & $\{0 ; 1 ; 1\}$ & $\{2 ; 2 ; 3\}$ & $\{2 ; 3 ; 5\}$ & $\{3 ; 5 ; 8\}$ \\
\hline 4 & 6 & $\{0 ; 0 ; 1\}$ & $\{0 ; 2 ; 3\}$ & $\{1 ; 2 ; 4\}$ & $\{1 ; 2 ; 4\}$ & $\{2 ; 3 ; 7\}$ \\
\hline 5 & 10 & $\{0 ; 0 ; 1\}$ & $\{0 ; 0 ; 1\}$ & $\{0 ; 1 ; 1\}$ & $\{0 ; 1 ; 2\}$ & $\{2 ; 1 ; 3\}$ \\
\hline \multicolumn{7}{|c|}{ Compostable Biopolymer } \\
\hline Expert & Confidence & 18 & 22 & 26 & 30 & 34 \\
\hline 1 & 9 & $\{0 ; 0 ; 1\}$ & $\{0 ; 0 ; 1\}$ & $\{0 ; 0 ; 1\}$ & $\{0 ; 1 ; 2\}$ & $\{1 ; 2 ; 4\}$ \\
\hline 2 & 10 & $\{0 ; 0 ; 1\}$ & $\{0 ; 1 ; 2\}$ & $\{1 ; 1 ; 3\}$ & $\{1 ; 2 ; 4\}$ & $\{2 ; 2 ; 5\}$ \\
\hline 3 & 9 & $\{0 ; 0 ; 0\}$ & $\{0 ; 0 ; 1\}$ & $\{0 ; 0 ; 1\}$ & $\{0 ; 1 ; 2\}$ & $\{1 ; 1 ; 2\}$ \\
\hline 4 & 7 & $\{0 ; 0 ; 1\}$ & $\{0 ; 0 ; 1\}$ & $\{0 ; 1 ; 2\}$ & $\{0 ; 1 ; 2\}$ & $\{1 ; 1 ; 4\}$ \\
\hline 5 & 5 & $\{0 ; 0 ; 1\}$ & $\{0 ; 1 ; 1\}$ & $\{0 ; 1 ; 2\}$ & $\{0 ; 1 ; 2\}$ & $\{0 ; 2 ; 2\}$ \\
\hline
\end{tabular}


Table 5. Cont.

\begin{tabular}{ccccccc}
\hline \multicolumn{7}{c}{ Jute-Rayon } \\
\hline Expert & Confidence & $\mathbf{1 8}$ & $\mathbf{2 2}$ & $\mathbf{2 6}$ & $\mathbf{3 0}$ & $\mathbf{3 4}$ \\
\hline 1 & 8 & $\{0 ; 0 ; 1\}$ & $\{0 ; 1 ; 2\}$ & $\{1 ; 1 ; 3\}$ & $\{1 ; 1 ; 4\}$ & $\{1 ; 2 ; 5\}$ \\
2 & 10 & $\{0 ; 1 ; 2\}$ & $\{1 ; 1 ; 2\}$ & $\{2 ; 2 ; 2\}$ & $\{2 ; 2 ; 5\}$ & $\{2 ; 3 ; 6\}$ \\
3 & 9 & $\{0 ; 0 ; 0\}$ & $\{0 ; 1 ; 2\}$ & $\{0 ; 1 ; 5\}$ & $\{1 ; 2 ; 6\}$ & $\{1 ; 4 ; 7\}$ \\
4 & 7 & $\{0 ; 0 ; 1\}$ & $\{0 ; 1 ; 1\}$ & $\{1 ; 1 ; 2\}$ & $\{1 ; 1 ; 2\}$ & $\{1 ; 1 ; 3\}$ \\
5 & 6 & $\{0 ; 0 ; 1\}$ & $\{0 ; 0 ; 1\}$ & $\{0 ; 1 ; 2\}$ & $\{1 ; 2 ; 3\}$ & $\{2 ; 3 ; 4\}$ \\
\hline
\end{tabular}

1 The polypropylene data is not presented due to it having $0 \%$ breakage in the surveys carried out.

The opinions shown in Tables 4 and 5 were added for each crop and treatment, and then the values obtained were defuzzified. The aggregations were obtained from the experts' opinions using the arithmetic means, probability, OWA, and AOWA for cellulose in tomatoes. These are the accumulated values up to the week indicated.

As can be seen in Table 4, at week 27, in tomatoes, for the cellulose treatment, the opinions of the five experts were $\{7 ; 11 ; 14\},\{9 ; 10 ; 12\},\{6 ; 8 ; 10\},\{7 ; 11 ; 13\}$, and $\{5 ; 5 ; 7\}$, which indicate the minimum, most possible, and maximum opinions. Thus, for example, for expert one, the most possible opinion was an $11 \%$ breakage, although this could range between $7 \%$ and $14 \%$. The vector of weights for the OWA was $\{0.30 ; 0.25 ; 0.20 ; 0.15 ; 0.10\}$, which is in line with other works, such as $[33,34]$, that use similar vectors. This means that the highest opinion, $\{7 ; 11 ; 14\}$, was assigned a weight of 0.30 , the second highest opinion, $\{7 ; 11 ; 13\}$, was assigned a weight of 0.25 , the third highest opinion, $\{9 ; 10 ; 12\}$, was assigned a weight of 0.20 , etc. The application of Expression (4) allows the obtainment of a triangular fuzzy number (TFN) whose lower $(\alpha)$, middle $(\beta)$, and upper $(\gamma)$ extremes were obtained as follows:

$$
\begin{gathered}
\alpha=7 \times 0.3+7 \times 0.25+9 \times 0.2+6 \times 0.15+5 \times 0.10=7.05 \\
\beta=11 \times 0.3+11 \times 0.25+10 \times 0.2+8 \times 0.15+5 \times 0.10=9.75 \\
\gamma=14 \times 0.3+13 \times 0.25+12 \times 0.2+10 \times 0.15+7 \times 0.10=12.05
\end{gathered}
$$

The defuzzification consisted of obtaining the crisp number that collected all the information of the mentioned triangular fuzzy number, using the expression $\mathrm{A}=(7.05+2 \times 9.75$ $+12.05) / 4=9.65$. The results for the other aggregators included the arithmetic mean, where the aggregation, using probabilities and AOWA, were 9.00,9.06, and 8.35, respectively. The use of different aggregators has been used in various works, such as [35,36]. From these data, a decision can be made to determine the most optimistic or maximum value, the most pessimistic or minimum value, or a conservative value that corresponds to intermediate values in ranking the criteria [34]. In this case, the average of said aggregators has been considered. The final average (week 27) of the four aggregations was 9.02. The percentage of failures of said period was obtained by a simple difference, comparing this percentage of failures with that of the previous period. Thus, in tomatoes, $2.46 \%$ of the breaks were concentrated between weeks 22 to 24 , and $2.29 \%$ between weeks 25 and 27. In spite of this, the risk in kilograms was higher during weeks 19 to 21 at $2052.53 \mathrm{~kg}$, since this percentage of pending kilograms was much higher and, therefore, the risk in Euros for this period was also higher (EUR 903.11).

Figure 3 shows the weekly changes in accumulated breakages, adding the information provided by the experts, using the arithmetic mean, the confidence assigned to each expert, OWAs, and AOWAs (Tables 4 and 5). The weighting vector for the OWA and AOWA was $\{0.30 ; 0.25 ; 0.20 ; 0.15 ; 0.10\}$, that is to say, the OWA assignation was 0.30 to the expert who provided the highest percentage, 0.25 to the second, etc. The AOWA assignation was 0.3 to the smallest, 0.25 to the second smallest, etc. The OWA operators (both the OWA and the AWOA) add information, provide values between the minimum and the maximum, and are very useful for representing the attitudinal character of the decision-maker [37]. Some 
works have unified the concept of probability with the OWA operators [38]. Here, both the OWAs and descending OWAs were considered together with the probability, which was made possible by the evaluation of the breaks that considered both the opinions provided by the experts, and confidence that each of them deserved. Therefore, from the aggregation carried out, it follows that:

- The breaks are higher in tomatoes than peppers in all the cases. Thus, taking the arithmetic mean (1) in tomatoes and defuzzifying the result, the value of cellulose in the tomato was 9.02, compared to 4.19 in the pepper; the value of cellulose + kraft paper was 7.58, compared to 3.45; the compostable biopolymer value was 4.01 , compared to 1.92; and in jute-rayon, the value was 6.63, compared to 2.92 . This was similar for the rest of the aggregators and for peppers;

- In general, the percentage of breakages within each crop was higher in cellulose, followed by cellulose + kraft paper, the compostable biopolymer, and, finally, juterayon. However, there are some points that should be noted;

- The aggregation using OWA or AOWA generated different absolute results, since the OWA was weighted more heavily to the higher results. In AOWA, it is weighted more heavily to the lower results. Therefore, all AOWAs generated a lower aggregate value (breakage percentage);

- The aggregation with OWA or AOWA generated the same order within each crop. However, the result of cellulose + kraft paper, using OWAs (4.06), was very similar to cellulose, which was 4.44 in peppers. This was due to the opinions of the best-valued experts who offered superior opinions. The aggregation, by both methods, presented very similar results (Figure 3 ).

- According to the confidence assigned to each expert (the second column of Tables 4 and 5), a similarity was observed for peppers with the cellulose (2.98) and jute-rayon (2.99) treatments, even though the arithmetic means differed by $0.70 \%$, because a group of experts was trusted more, thus showing similar results.

In summary, when making aggregations, the arithmetic mean should not be considered as the unique methodology, because some experts may sometimes be more trusted than others, either because they have more knowledge, or because their predictions are usually more accurate. It should be kept in mind that OWAs have been used in a wide variety of problems $[39,40]$, and are especially useful for those occasions in which the opinions of experts are subject to high doses of uncertainty. Therefore, giving more importance to the opinions that present higher values when making decisions is preferred. On the contrary, AOWAs are used for those cases in which it is desirable to give more importance to the lower elements when making a decision. In this way, a more complete representation of the aggregation process has been shown [41], highlighting not only the central values (the arithmetic mean) but also the upper (OWA) and the lower (AOWA) ones, as well as the probability assigned to each expert.

Figure 4 shows the weekly changes of risk in tomato and pepper crops for each treatment. In general, the most significant risks in tomatoes were found between weeks 21 and 24, and decreased at the end of the season. Although the percentage of breaks did not decrease, less volume remained to be collected. In peppers, the risk was much lower, except with cellulose; although an uptick in week 30 was observed, the risk decreased from week 26. It must be taken into account that the tutoring methods analyzed in this study were the hook-and-loop trellising system for the tomato, and the conventional or bundle method for the pepper. In the case of using Dutch pruning in pepper, the Dutch pruning trellising would have been used [6], which is a tutoring technique that is similar to that of the tomato. Therefore, the damage and losses in peppers using this other system would be different from those obtained in our study, although the results may have been similar to tomatoes. The results obtained led us to observe a greater risk in the vertical system than in the horizontal one, and these results can be extrapolated to other crops where this type of system is also utilized, such as for aubergines (eggplants) and cucumbers. 


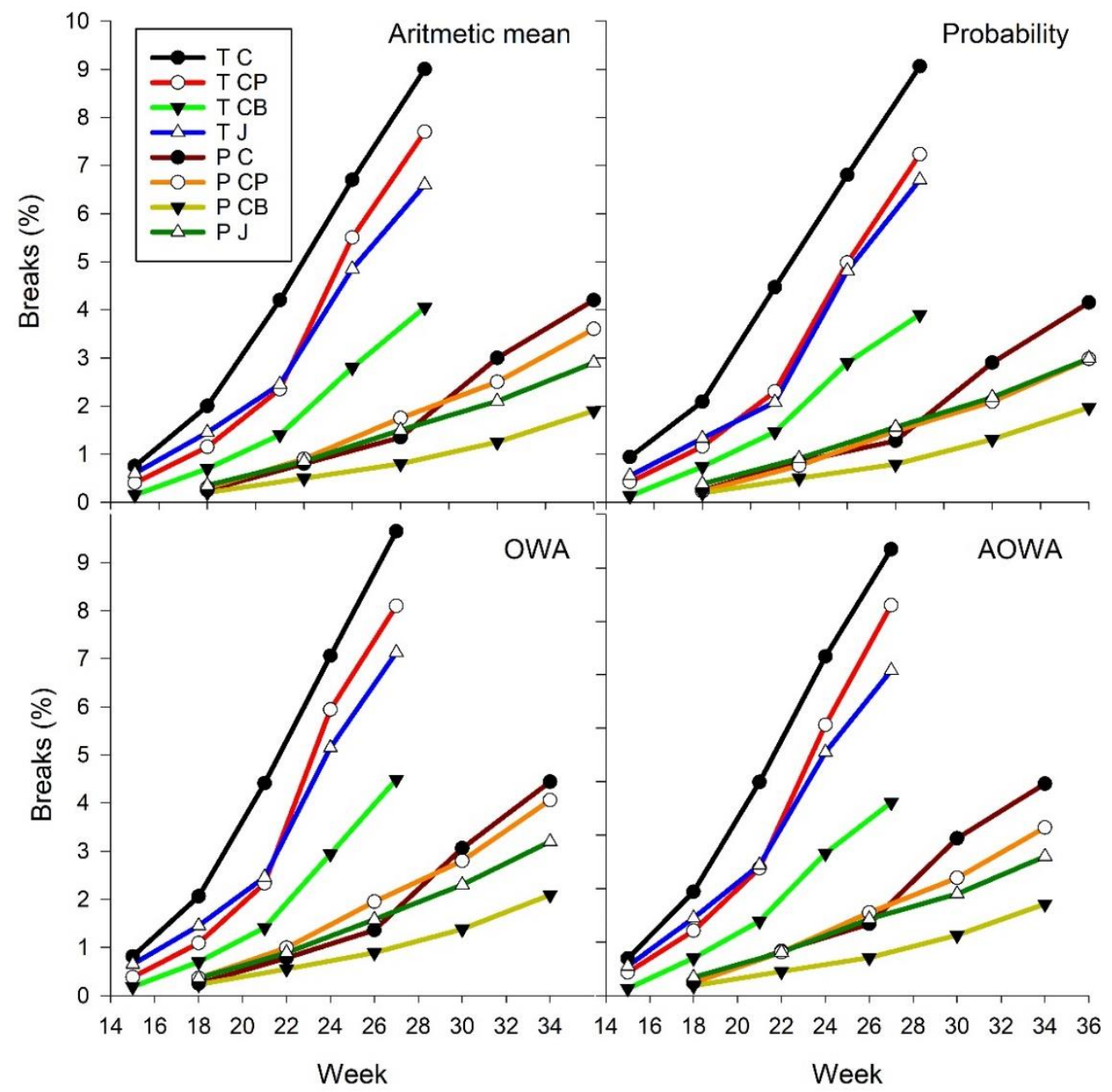

Figure 3. Changes in the percentage of breakages accumulated in tomatoes $(\mathrm{T})$ and peppers $(\mathrm{P})$ in the treatments with cellulose $(\mathrm{C}$, cellulose + kraft Paper (CP), compostable biopolymer (CB), and jute-rayon (J), using, as aggregates, the arithmetic means, probability $(\mathrm{P})$, ordered weighted average (OWA), and ascending ordered weighted average (AOWA).

Table 6 summarizes the production before and after, considering the risk of breakage in tomatoes and peppers. The risk of breakage was obtained by adding the information provided by the experts using the aggregators (1) to (5) and multiplying said value, once defuzzified, by the pending production (Table 3). Table 6 shows the total production and the total risk of breakage in kilos. The net production was obtained by reducing the production by the risk of breakage. The risk, in Euros, was the result of multiplying the risk of breakage by the average sale price. The risk of breakage was higher in cellulose, with this biopolymer presenting a lower risk, both in tomatoes and peppers. A previous study also showed that this polymer, made from biodegradable/compostable material [42], had an excellent duration without appreciating breakage. 


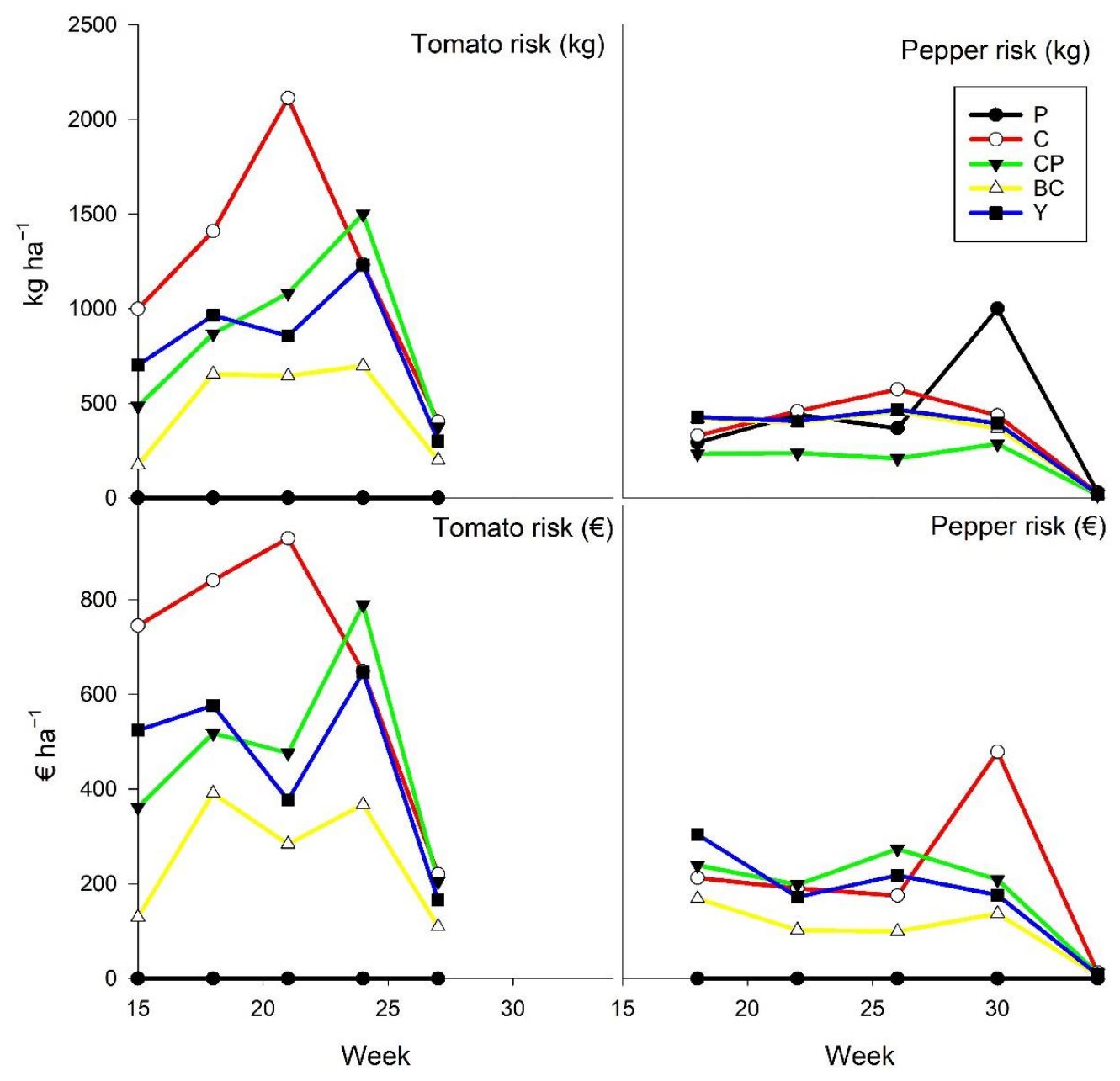

Figure 4. Tomato and pepper weekly risk for polypropylene $(\mathrm{P})$, cellulose $(\mathrm{C})$, cellulose $+\mathrm{kraft}$ paper $(\mathrm{CP})$, compostable biopolymer (CB), and jute-rayon (J).

Table 6. Risk in volume (kg), risk (EUR), and net profit in tomatoes and peppers.

\begin{tabular}{lrrrrr}
\hline Tomato & Polypropylene & Cellulose & $\begin{array}{r}\text { Cellulose }+ \\
\text { Kraft Paper }\end{array}$ & $\begin{array}{r}\text { Compostable } \\
\text { Biopolymer }\end{array}$ & Jute-Rayon \\
\hline Breakages (\%) & 0.00 & 9.02 & 7.58 & 4.01 & 6.63 \\
Production (kg) & 119,730 & 119,730 & 119,730 & 119,730 & 119,730 \\
Risk of breakage (kg) & 0 & 6029 & 4308 & 2371 & 4055 \\
Net production (kg) & 119,730 & 113,701 & 115,422 & 117,359 & 115,675 \\
Risk (EUR) & 0 & 3314 & 2349 & 1281 & 2288 \\
Pepper & Polypropylene & Cellulose & Cellulose + & Compostable & Kute-Rayon \\
& & & Baper & Biopolymer & \\
\hline Breakages (\%) & 0.00 & 4.19 & 3.45 & 1.92 & 2.92 \\
Production (kg) & 117,065 & 117,065 & 117,065 & 117,065 & 117,065 \\
Risk of breakage (kg) & 0 & 2130 & 1823 & 979 & 1662 \\
Net production (kg) & 117,065 & 114,936 & 115,242 & 116,086 & 115,404 \\
Risk (EUR) & 0 & 1070 & 931 & 514 & 879 \\
\hline
\end{tabular}

\subsection{Costs}

Table 7 shows the summary of costs for tomatoes and peppers, except for the raffia itself, which is shown in detail in Table 8 . The costs were the average of the two seasons. They were classified into overheads and annual costs $[43,44]$. For the former, the amortization costs were linear, considering a useful life of 25 years for the greenhouse structure; ten years for the drip irrigation installation, and three years for the plastic cover. The annual 
costs were separated into variable costs and fixed costs. Variable costs included harvesting costs, which were considered as EUR $0.029 \mathrm{~kg}^{-1}$ for tomatoes and EUR $0.056 \mathrm{~kg}^{-1}$ for peppers. For fix costs, labor costs were included at EUR $5.71 \mathrm{~h}^{-1}$, with a social security cost of $35.63 \%$, a machinery cost of EUR $36 \mathrm{~h}^{-1}$, and the water cost of EUR $0.23 \mathrm{~m}^{-3}$. The water cost was the same as the cost in the study by Lopez-Marín et al. [16]. On their part, García-García [45] used a cost of EUR $0.23 \mathrm{~m}^{-3}$. In any case, despite these similarities, it must be kept in mind that the cost of water differs significantly from one area to another [46] and can reach values of EUR $0.26 \mathrm{~m}^{-3}$ [47]. It should also be kept in mind that this cost is linked to the cost of energy in some areas, since it is necessary to raise the water from the river valley to higher areas. These costs do not include the removal costs of the non-biodegradable raffia or those of the raffia shown in Table 7.

Table 7. Overhead costs and annual costs ${ }^{1}$ per hectare (EUR).

\begin{tabular}{lrr}
\hline Concept & Tomato & Pepper \\
\hline 1. Overhead costs & 6422 & 6422 \\
1.1. Greenhouse installation & 3462 & 3462 \\
1.2. Drip irrigation & 460 & 460 \\
1.3. Plastic cover & 2500 & 2500 \\
2. Annual costs & 44,918 & 40,881 \\
2.1. Annual fixed costs & 40,271 & 32,065 \\
2.1.1. Non-harvesting labor (crop preparation, rest of labor, social security) & 15,787 & 9013 \\
2.1.2. Seeds + trays & 5450 & 5925 \\
2.1.3. Treatments (fertilizers, phytosanitary, soil disinfection) & 14,185 & 12,404 \\
2.1.4. Water & 2000 & 1722 \\
2.1.5. Energy & 50 & 50 \\
2.1.6. Supplies & 400 & 350 \\
2.1.7. Additional whitewash & 260 & 260 \\
2.1.8. Machinery & 1498 & 1700 \\
2.1.9. Administrative costs & 150 & 150 \\
2.1.10. Taxes & 491 & 491 \\
2.2. Annual variable costs (harvesting labor cost and social security) & 4647 & 8816 \\
Total & 51,340 & 47,303 \\
\hline
\end{tabular}

${ }^{1}$ Average of Two Seasons.

Table 8. Cost of raffia in tomato and pepper cultivation.

\begin{tabular}{|c|c|c|c|c|c|c|}
\hline Tomato & $\begin{array}{l}\text { Tensile Strength at } \\
\text { Break (kg) }\end{array}$ & $\mathrm{m} \cdot \mathrm{kg}^{-1}$ & $\operatorname{kg~ha}^{-1}$ & 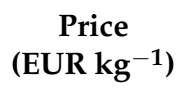 & $\begin{array}{c}\text { Cost } \\
\left(\text { EUR ha }^{-1}\right)\end{array}$ & $\begin{array}{l}\text { Removal Cost } \\
\left(\text { EUR ha }^{-1}\right)\end{array}$ \\
\hline Polypropylene & 47 & 800 & 150.0 & 2.14 & 321.0 & 720 \\
\hline Cellulose & 35 & 600 & 200.0 & 13.31 & 2662.0 & No \\
\hline Cellulose + kraft paper & 20 & 550 & 218.2 & 5.55 & 1210.9 & No \\
\hline Compostable biopolymer & 35 & 550 & 218.2 & 6.2 & 1352.7 & No \\
\hline Jute-rayon & 28 & 345 & 347.8 & 3 & 1043.5 & No \\
\hline \multicolumn{7}{|l|}{ Pepper } \\
\hline Polypropylene & 47 & 800 & 125 & 2.14 & 267.5 & 600 \\
\hline Cellulose & 20 & 700 & 142.9 & 14.04 & 2005.1 & No \\
\hline Cellulose + kraft paper & 20 & 550 & 181.8 & 5.55 & 1009.1 & No \\
\hline Compostable biopolymer & 27 & 700 & 142.9 & 6.2 & 885.7 & No \\
\hline Jute-rayon & 28 & 345 & 289.9 & 3 & 869.6 & No \\
\hline
\end{tabular}

Table 8 shows the cost of the raffia for each of the treatments. The need of 100,000 and $120,000 \mathrm{~m}$ of raffia were estimated for peppers and tomatoes, respectively. In tomatoes, polypropylene costs were $3.03 \%$ of the profit, and the biodegradable materials ranged from $13.09 \%$ for jute-rayon to $49.83 \%$ for cellulose. The costs for peppers were somewhat lower; for polypropylene, it was $2.15 \%$ of the profit, and for the biodegradable materials, the cost ranged from $19.57 \%$ for cellulose, to $7.43 \%$ for the compostable biopolymer. Table 9 
summarizes the income, previous costs, raffia costs, and final benefit for each treatment in tomatoes and peppers. For polypropylene, removal costs were also included.

Table 9. Summary of income, previous costs, raffia costs, and final benefit for each treatment in tomatoes and peppers.

\begin{tabular}{lrrrrr}
\hline Tomatoes & Polypropylene Cellulose & $\begin{array}{r}\text { Cellulose }+ \\
\text { Kraft Paper }\end{array}$ & $\begin{array}{r}\text { Compostable } \\
\text { Biopolymer }\end{array}$ & $\begin{array}{r}\text { Jute- } \\
\text { Rayon }\end{array}$ \\
\hline Income (without risk) & $62,642.68$ & $62,642.68$ & $62,642.68$ & $62,642.68$ & $62,642.68$ \\
Breakage risk (EUR) & 0.00 & 3313.77 & 2348.97 & 1280.56 & 2288.35 \\
Net income & $62,642.68$ & $59,328.91$ & $60,293.71$ & $61,362.12$ & $60,354.34$ \\
Costs without raffia & 51,340 & 51,340 & 51,340 & 51,340 & 51,340 \\
Raffia removal costs & 720.00 & & & & \\
Raffia acquisition costs & 321.00 & 2662.00 & 1210.91 & 1352.73 & 1043.48 \\
Total costs & $52,381.32$ & $54,002.32$ & $52,551.23$ & $52,693.04$ & $52,383.80$ \\
\hline Benefit & $10,261.36$ & 5326.59 & 7742.48 & 8669.08 & 7970.54 \\
\hline Peppers & & & Cellulose + & Compostable & Jute- \\
& Polypropylene & Cellulose & Kraft Paper & Biopolymer & Rayon \\
\hline Income (without risk) & $60,626.81$ & $60,626.81$ & $60,626.81$ & $60,626.81$ & $60,626.81$ \\
Breakage risk (EUR) & 0 & 3314 & 2349 & 1281 & 2288 \\
Net income & 60,627 & 57,313 & 58,278 & 59,346 & 58,338 \\
Costs without raffia & 47,303 & 47,303 & 47,303 & 47,303 & 47,303 \\
Raffia removal costs & 600.00 & 0.00 & 0.00 & 0.00 & 0.00 \\
Raffia acquisition costs & 267.50 & 2005.14 & 1009.09 & 885.71 & 869.57 \\
Total costs & $48,170.94$ & $49,308.58$ & $48,312.53$ & $48,189.15$ & $48,173.00$ \\
\hline Benefit & $12,455.87$ & $10,248.18$ & $11,383.19$ & $11,923.31$ & $11,574.79$ \\
\hline & & & & &
\end{tabular}

\subsection{Productivity Indicators}

Table 10 shows the raffia productivity indices. These indicators are similar to those used in other studies for other elements, such as water $[16,48]$. The jute-rayon treatment had the highest consumption, in kilograms, in both tomatoes and peppers. However, all of them were higher than the conventional one, with $150 \mathrm{~kg} \mathrm{ha}^{-1}$ used, where the latter was the one that presented higher rates in the two crops. The maximum cost that the raffia could raise was calculated so that the business did not enter into losses. In tomatoes, the break-even point was much higher, as it presented a lower consumption, with cellulose being the one that allowed a higher price. As can be observed, the break-even point of raffia was much higher than the current market values in all treatments, so its price variations, even affecting the profitability of the business, would not force it to enter into losses. The break-even point was also high in peppers, ranging from 45.97 for jute-rayon to 101.79 for polypropylene.

The highest values were reached in polypropylene regarding production efficiency, productivity, and economic efficiency. On its part, within the biodegradable polymers, cellulose presented the best indices of productive efficiency and productivity. Concerning economic efficiency, the compostable biopolymer presented the highest value within the biodegradable materials. Jute-rayon had the worst indices because the risk of breakage was considered, reducing actual production and, consequently, reducing production efficiency. It also reduced income and, therefore, affected productivity, and, finally, profit was reduced, which affected economic efficiency. 
Table 10. Indexes of raffia productivity.

\begin{tabular}{|c|c|c|c|c|c|}
\hline Tomatoes & Polypropylene & Cellulose & $\begin{array}{l}\text { Cellulose+ } \\
\text { Kraft Paper }\end{array}$ & $\begin{array}{c}\text { Compostable } \\
\text { Biopolymer }\end{array}$ & Jute-Rayon \\
\hline $\mathrm{Kg}_{\mathrm{raffia}} \mathrm{ha}^{-1}$ & 150.00 & 200.00 & 218.18 & 218.18 & 347.83 \\
\hline Productive efficiency & 798.20 & 567.87 & 529.02 & 537.89 & 332.57 \\
\hline Productivity (EUR kg ${ }^{-1}$ ) & 417.62 & 296.29 & 276.35 & 281.24 & 173.52 \\
\hline Economic efficiency (EUR kg ${ }^{-1}$ ) & 84.08 & 38.03 & 46.26 & 50.50 & 29.67 \\
\hline Break-even point of the raffia (EUR kg-1) & 86.22 & 51.34 & 51.81 & 56.70 & 32.67 \\
\hline Peppers & Polypropylene & Cellulose & $\begin{array}{l}\text { Cellulose+ } \\
\text { Kraft Paper }\end{array}$ & $\begin{array}{l}\text { Compostable } \\
\text { Biopolymer }\end{array}$ & Jute-Rayon \\
\hline $\mathrm{Kg}_{\mathrm{raffia}} \mathrm{ha}^{-1}$ & 125.00 & 142.86 & 181.82 & 142.86 & 289.86 \\
\hline Productive efficiency & 936.52 & 804.55 & 633.83 & 812.60 & 398.14 \\
\hline Productivity (EUR kg ${ }^{-1}$ ) & 485.01 & 424.39 & 333.45 & 424.39 & 209.16 \\
\hline Economic efficiency (EUR kg ${ }^{-1}$ ) & 99.65 & 71.74 & 62.61 & 83.46 & 39.93 \\
\hline Break-even point of the raffia (EUR kg-1) & 101.79 & 93.26 & 73.28 & 93.26 & 45.97 \\
\hline
\end{tabular}

Table 11 shows the net present value (NPV) and annualized value for tomatoes and peppers for a discount rate of $5 \%$, obtained according to expressions (6) and (7), respectively. The risk-free discount rate in Spain was obtained from the 10-year state bond quote [49], which stands at $0.41 \%$. Regarding the risk premium, $4.59 \%$ was considered somewhat lower than that assumed by Fernández et al. [10], which indicated a range between 5.0 and $5.5 \%$, and was slightly lower than the $5.25 \%$ considered by Lopez-Marín et al. [42], due to the decrease in interest rates produced in the Eurozone. The highest values were achieved by peppers, where all the treatments were positive, in line with the research by Lopez-Marín et al. [14], who concluded that the use of liming allowed the obtainment of a positive yield. On the contrary, all the treatments showed negative results for a $5 \%$ discount rate, except for the control treatment in tomatoes. Similarly, Lopez-Marín et al. [27] obtained a probability for results of $86 \%$ for the Cayetano variety, and $74 \%$ for the Pompeo variety (in the absence of cover). The pepper's internal rate of return (IRR) (8) oscillated between $8.83 \%$ in the control and $5.86 \%$ with cellulose, whereas in tomatoes, the control offered an IRR of $5.88 \%$, while the rest were less than $5 \%$ (as expected, because they have an NPV < 0). Still, it should be pointed out that in cellulose, the IRR was negative, and this was because, within the useful life of the greenhouse (25 years), the investment was not recovered or was found at zero cost. The payback period was 30.10 years for cellulose, much higher than the rest, ranging between 15.63 and 20.12 years because of the percentage of breakages that significantly reduced the net operating income. In peppers, the payback period (PB) (9) was between 12.87 (control) and 15.65 (cellulose).

Table 11. Obtaining the net present value (NPV), annualized value, internal rate of return (IRR), and payback period ( $\mathrm{PB})$ for tomatoes and peppers by treatment.

\begin{tabular}{lrrrrr}
\hline Tomato & Polypropylene Cellulose & $\begin{array}{r}\text { Cellulose }+ \\
\text { Kraft Paper }\end{array}$ & $\begin{array}{r}\text { Compostable } \\
\text { Biopolymer }\end{array}$ & Jute-Rayon \\
\hline NPV & 8580.75 & $-60,969.62$ & $-26,920.25$ & $-13,860.87$ & $-23,705.99$ \\
Annualized value & 608.83 & -4325.94 & -1910.06 & -983.46 & -1682.00 \\
IRR & 0.0588 & -0.0342 & 0.0194 & 0.0349 & 0.0233 \\
PB & 15.63 & 30.10 & 20.71 & 18.50 & 20.12 \\
\hline \multirow{2}{*}{ Pepper } & Polypropylene & Cellulose & cellulose + & Compostable & Jute-Rayon \\
& & & Kraft Paper & Biopolymer & \\
\hline NPV & $39,509.99$ & 8395.01 & $24,391.72$ & $32,004.16$ & $27,092.16$ \\
Annualized value & 2803.33 & 595.65 & 1730.65 & 2270.77 & 1922.26 \\
IRR & 0.0883 & 0.0586 & 0.0743 & 0.0814 & 0.0769 \\
PB & 12.87 & 15.65 & 14.09 & 13.45 & 13.85 \\
\hline
\end{tabular}


Figure 5 shows the maximum percentage of breakages that a farm can withstand to continue obtaining profit, according to expression (10). The percentages were lower in the tomato, as they presented a lower income. In addition, the percentages were very similar for all treatments, as the cost of raffia was very low compared to the total benefits. In peppers, the benefits were higher, as it allowed a higher percentage of breakages, and the costs of the raffia were higher in the cellulose treatment, which is why it allowed a lower percentage of breakages than the rest of the treatments. The harvesting cost considered was EUR $0.029 \mathrm{~kg}^{-1}$ for tomatoes and EUR $0.056 \mathrm{~kg}^{-1}$ for peppers. In other studies, the break-even point of other elements, such as water, was also obtained [50]. However, given the large amount used, its break-even point was much closer to the market price than in the case of raffia.

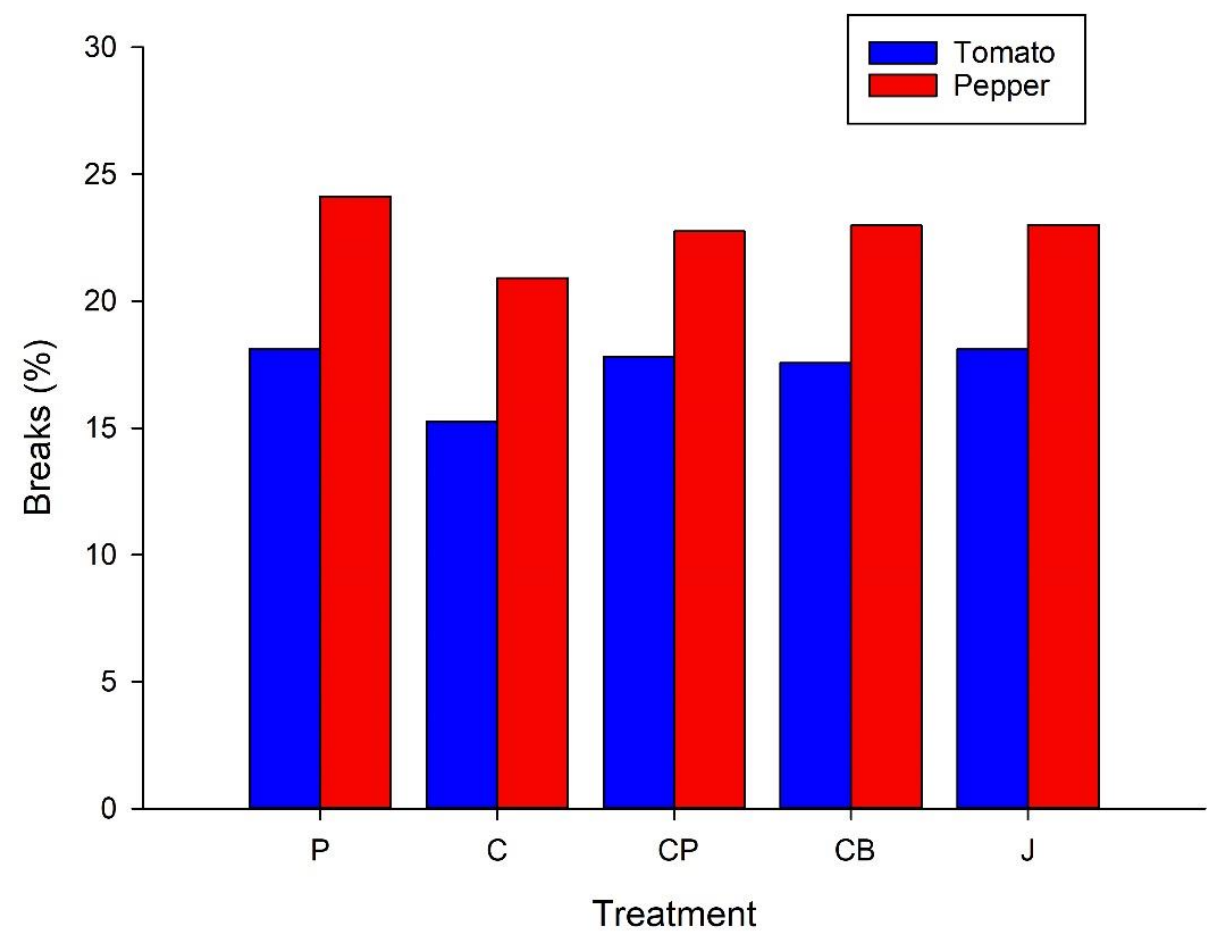

Figure 5. Maximum breakage percentage by treatment and culture for polypropylene (P), cellulose (C), cellulose + kraft paper (CP), compostable biopolymer (CB), and jute-rayon (J).

\section{Conclusions}

Current horticultural production systems use many synthetic materials, such as polyethylene. An example of this is raffia, whose removal is extremely difficult, which is why the present study analyzed the economic implications of its replacement with biodegradable polymers. The main conclusions obtained are the following:

- It is of particular importance to determine the final percentage of plantation breakages, and the date of their breakage, since the earliest breakages generated a more significant loss than those that occurred at the end of the season;

- The breaks were higher in tomatoes than in peppers, with the compostable biopolymer being the treatment that showed lower breaks in both cases. On the contrary, cellulose was the one that presented a higher percentage of breakages in both crops;

- The economic risk of breakage was higher in tomatoes than peppers with cellulose, followed by cellulose + kraft paper. The most significant risk was concentrated in the central weeks of harvesting, so the strategies must be aimed not only at reducing breakages, but also at increasing the temporary duration of the materials;

- The incorporation of biodegradable raffia reduced the profit of the farms since its price was higher, and they presented the risk of breakage, although there was no cost 
associated to the removal of the raffia. Cellulose was the most affected material, with the compostable biopolymer having a more favorable behavior than the control;

- Productivity indicators were affected by lower profits. In spite of this, the IRR was negative for cellulose in tomatoes, as the lower benefits did not allow the initial investment to be recovered until 30.10 years.

Author Contributions: Conceptualization, J.L.-M., A.G. and J.M.B.-M.; methodology, J.L.-M. and J.M.B.-M.; software, J.M.B.-M.; validation, J.L.-M., F.M.d.A. and J.M.B.-M.; formal analysis, J.M.B.-M.; investigation J.L.-M., A.G. and J.M.B.-M.; resources, J.L.-M., and writing-original draft preparation, J.L.-M. and J.M.B.-M.; writing-review and editing, J.L.-M. and J.M.B.-M.; supervision F.M.d.A., M.C.P. and J.M.B.-M.; project administration, J.L.-M. and J.M.B.-M.; funding acquisition F.M.d.A. and J.L.-M. All authors have read and agreed to the published version of the manuscript.

Funding: This work was founded by the European Regional Development Fund (ERDF) 80\%-Region de Murcia (FEDER 1420-30).

Institutional Review Board Statement: Not applicable.

Informed Consent Statement: Not applicable.

Data Availability Statement: Data is contained within the article.

Conflicts of Interest: The authors declare no conflict of interest and the funders had no role in the design of the study; in the collection, analyses, or interpretation of data; in the writing of the manuscript, or in the decision to publish the results.

\section{References}

1. Siwek, P.; Domagala-Swiatkiewicz, I.; Bucki, P.; Puchalski, M. Biodegradable agroplastics in 21st century horticulture. Polimery 2019, 64, 480-486. [CrossRef]

2. $\quad$ Crippa, M.; De Wilde, B.; Koopmans, R.; Leyssens, J.; Linder, M.; Muncke, J.; Ritschkof, A.C.; Van Doorsselaer, K.; Velis, C.; Wagner, M.A. Circular Economy for Plastics_Insights from Research and Innovation to Inform Policy and Funding Decisions; Smet, M., De Linder, M., Eds.; European Commission: Brussels, Belgium, 2019.

3. Scarascia-Mugnozza, G.; Sica, C.; Russo, G. Plastic Materials in European Agriculture: Actual Use and Perspectives. J. Agric. Eng. 2012, 42, 15-28. [CrossRef]

4. Gázquez, J.C.; Meca, D.E.; Baeza, E.; Pérez, C.; García, R.; López, J.C. Evaluación de Tres Sistemas de Guiado para Tomate en Invernadero en Clima Cálido: Descuelgue Tradicional; Tradicional Intensivo y Perchas (Tipo Holandés). Actas Hortic. 2012, 60, 704-707.

5. Lopez-Marin, J.; Galvez, A.; Porras, I.; Brotons-Martinez, J.M. Use of a PSNM to Increase Precocity and Its Benefits in GreenhouseGrown Sweet pepper. J. Agric. Sci. Technol. 2017, 19, 1005-1018.

6. López-Marín, J.; Angosto, J.L.; González, A. El Cultivo de Pimientos en el Campo de Cartagena; Serie Monográfica. Tecnologías de Horticultura Mediterránea: Cultivo de pimiento; El Cultivo de Pimientos en el Campo de Cartagena: Valencia, Spain, 2013 ; p. 59.

7. Guerrini, S.; Borreani, G.; Voojis, H. Biodegradable Materials in Agriculture: Case Histories and Perspectives. In Soil Degradable Bioplastics for a Sustainable Modern Agriculture; Malinconico, M., Ed.; Springer: Berlin/Heidelberg, Germany, 2017 ; pp. $35-65$.

8. Stegmann, P.; Londo, M.; Junginger, M. The circular bioeconomy: Its elements and role in European bioeconomy clusters. Resour. Conserv. Recycl. X 2020, 6, 100029. [CrossRef]

9. Duque-Acevedo, M.; Belmonte-Ureña, L.J.; Toresano-Sánchez, F.; Camacho-Ferre, F. Biodegradable Raffia as a Sustainable and Cost-Effective Alternative to Improve the Management of Agricultural Waste Biomass. Agronomy 2020, 10, 1261. [CrossRef]

10. Fernández, P.; Aguirreamalloa, J.; Corres, L. Prima de Riesgo Utilizada en el Mercado: Encuesta 2011; Documento de Investigación DI-921, Mayo; IESE Business School, Universidad de Navarra: Barcelona, Spain, 2011; Available online: https:/ / media.iese.edu/ research/pdfs/DI-0921.pdf (accessed on 10 December 2021).

11. Brotons, J.M. Supuestos de Valoración de Inversiones: Métodos Clásicos y Opciones Reales; Universidad Miguel Hernández: Elche, Spain, 2017.

12. Lopez-Marín, J.; Galvez, A.; del Amor, F.M.; Brotons, J.M. The Financial Valuation Risk in Pepper Production. The Use of Decoupled Net Present Value. Mathematics 2021, 9, 13. [CrossRef]

13. DOCE. Reglamento (CE) No 790/2000 de la Comisión de 14 de Abril de 2000 por el que se Establecen las Normas de Comercialización de los Tomates; Diario Oficial de las Comunidades Europeas: Luxembourg, 15 April 2000; pp. L95/24-L95/29.

14. López-Marín, J.; Porras, I.; Ros, C.; Brotons-Martínez, J.M. Study of the performance of sweet pepper (Capsicum annuum) crop in greenhouses with the use of shading. ITEA-Inf. Téc. Econ. Agrar. 2016, 112, 57-71.

15. Lopez-Marin, J.; Brotons-Martinez, J.M.; Galvez, A.; Porras, I. Pepper grafting (Capsicum annuum): Benefits and profitability. ITEA 2016, 112, 127-146. 
16. López-Marin, J.; Romero, M.; Gálvez, A.; del Amor, F.M.; Piñero, M.C.; Brotons-Martinez, J.M. The Use of Hydromulching as an Alternative to Plastic Films in an Artichoke (Cynara Cardunculus cv. Symphony) Crop: A Study of the Economic Viability. Sustainability 2021, 13, 5313. [CrossRef]

17. CARM. Consejería de Agricultura de la Región de Murcia. 2021. Available online: https://caamext.carm.es/esamweb/faces/ vista/seleccionPrecios.jsp (accessed on 27 November 2021).

18. Zadeh, L.A. Fuzzy Sets. Inf. Control 1965, 8, 338-353. [CrossRef]

19. Yager, R.R. On ordered weighted averaging aggregation operators in multi-criteria decision making. IEEE Trans. Syst. Man Cybern. 1988, 18, 183-190. [CrossRef]

20. Yager, R.R. Applications and extensions of OWA aggregations. Int. J. Man Mach. Stud. 1992, 37, 103-122. [CrossRef]

21. Welch, I. Corporate Finance: An Introduction; Prentice Hall: New York, NY, USA, 2009.

22. Brotons, J.M. Matemáticas Financieras. Introducción; Universidad Miguel Hernández: Elche, Spain, 2014.

23. Brotons Martinez, J.M.; Galvez, A.; Cahez-Rivera, R.; Marín, J.L. The Use of Fuzzy Decoupled Net Present Value in pepper production. In Proceedings of the XXI Sigef Congress- “Digital Era and Fuzzy Applications in Management and Economy", Monterrey, Mexico, 7 July 2021.

24. Ballestero, E. Economía de la Empresa Agraria y Alimentaria; Mundi-Prensa: Madrid, Spain, 2000; p. 416. (In Spanish)

25. Marcillo-Cedeño, C.; Aguilar-Guijarro, C.; Gutiérrez-Jaramillo, N. Análisis financiero: Una herramienta clave para la toma de decisiones de gerencia. 593 Digit. Publ. CEIT 2021, 6, 87-106. [CrossRef]

26. Plakias, Z.T. Cost-benefit analysis as a tool for measuring economic impacts of local food systems: Case study of an institutional sourcing change. J. Sci. Food Agric. 2021, 10, 161-185. [CrossRef]

27. Lopez-Marin, J.; Rodriguez, M.; Del Amor, F.M.; Galvez, A.; Brotons-Martinez, J.M. Cost-benefit Analysis of Tomato Crops under Different Greenhouse Covers. J. Agric. Sci. Technol. 2019, 21, 235-248.

28. Plastics-Evaluation of Compostability_Test Scheme and Specifications; UNE-EN14995; European Committee for Standardization: Madrid, Spain, 2007; p. 19.

29. Bernal, Ó.R.; Pérez, M.D.; Sánchez, F.T.; Ferre, F.C. Utilización de rafias biodegradables para el entutorado del cultivo de tomate en ciclo largo bajo invernadero. Terralia 2008, 65, 32-34.

30. Ministerio de Agricultura, Pesca y Alimentación. Estrategia Nacional de los Programas Operativos Sostenibles a Desarrollar por las Organizaciones de Productores de Frutas y Hortalizas; Ministerio de Agricultura, Pesca y Alimentación: Madrid, Spain, 2017.

31. European Commission. A Sustainable Bioeconomy for Europe: Strengthening the Connection between Economy, Society and the Environment. COM(2018) 673 Final; European Commission: Brussels, Belgium, 2018.

32. Brotons Martínez, J.M.; Camara Zapata, J.M. Selection of tomato cultivation systems under sustainability criteria. Fuzzy Econ. Rev. 2020, 25, 35-49. [CrossRef]

33. Brotons-Martínez, J.M.; Martínez-Perez, F.; Solano-Jimenez, J.; Cámara-Zapata, J.M. Application of ordered weighted average to adapt continuous assessment in an engineering physics course due to covid-19. In Proceedings of the INTED2021 15th Annual International Technology, Education and Development Conference, virtual, 8-9 March 2021.

34. Casanovas, M.; Torres-Martínez, A.; Merigó-Lindahl, J. Decision making processes of non-life insurance pricing using fuzzy logic and OWA operators. Econ. Comput. Econ. Cyb. 2015, 49, 169-187.

35. León-Castro, E.; Espinoza-Audelo, L.F.; Merigó, J.M.; Herrera-Viedma, E.; Herrera, F. Measuring volatility based on ordered weighted average operators: The case of agricultural product prices. Fuzzy Sets Syst. 2021, 422, 161-176. [CrossRef]

36. Reig-Mullor, J.; Brotons-Martinez, J.M. The evaluation performance for commercial banks by intuitionistic fuzzy numbers: The case of Spain. Soft Comput. 2021, 25, 9061-9075. [CrossRef]

37. Merigó, J.M. Probabilities in the OWA operator. Expert Syst. Appl. 2012, 39, 11456-11467. [CrossRef]

38. Yager, R.R.; Engemann, K.J.; Filev, D.P. On the concept of immediate probabilities. Int. J. Intell. Syst. 1995, 10, 373-397. [CrossRef]

39. Beliakov, G.; Pradera, A.; Calvo, T. Aggregation Functions: A Guide for Practitioners; Springer: Berlin, Germany, 2007.

40. Yager, R.; Kacprzyk, J.; Beliakov, G. Recent Developments in the Ordered Weighted Averaging Operators: Theory and Practice.Studies in Fuzziness and Soft Computing; Yager, R.R., Kacprzyk, J., Beliakov, G., Eds.; Springer: Berlin/Heidelberg, Germany, 2011; Volume 265.

41. Merigó, J.M. Decision-making under risk and uncertainty and its application in strategic management. J. Bus. Econ. Manag. 2015, 16, 93-116. [CrossRef]

42. Verlinde, W. Bioplastics and weed control textiles. In Proceedings of the AMI Agricultural Film 2011, Barcelona, Spain, 7-9 November 2011. 2011 Oral Presentation.

43. Engindeniz, S. Economic analysis of processing tomato growing: The case study of Torbali, west Turkey. Span. J. Agric. Res. 2007, 7,7-15. [CrossRef]

44. Engindeniz, S.; Tüzel, Y. The Determination of Cost and Profitability of Organic Vegetable Production in Greenhouse: A Case Study for Turkey, Organic Agriculture in the Mediterranean Basin. In Proceedings of the International Symposium Organic Agriculture, Agadir, Morocco, 7-10 October 2001; Hanafi, A., Kenny, L., Eds.; I.A.V. Hassan II, Agadir, Morocco. 2001; pp. 434-442.

45. García-García, J. Estructura de Costes de las Orientaciones Productivas Agrícolas de la Región de Murcia: Horticultura al Aire Libre y Bajo Invernadero; Serie Técnica, Consejería de Agua, Agricultura, Ganadería, Pesca y Medio Ambiente: Murcia, Spain, 2020.

46. García, J.G. Evaluación Económica y Eficiencia del Agua de Riego en Frutales de Regadío; Consejería de Agricultura y Agua: Murcia, Spain, 2007. 
47. Rigby, D.; Alcón, F.; Burton, M. Supply Uncertainty and the Economic Value of Irrigation Water EUR Rev. Agric. Econ. Eur. Rev. Agric. Econ. 2010, 37, 97-117. [CrossRef]

48. García, J.; Contreras-López, J.; Usai, F.; Visani, D.C. Economic Assessment and Socio-Economic Evaluation of Water Use Efficiency in Artichoke Cultivation. Open J. Account. 2013, 2, 45-52. [CrossRef]

49. Bolsas y Mercados. Boletín Diario de Liquidación de Deuda Pública y Renta Fija Privada. 2021. Available online: https:/ / www.bmemarketdata.es/docs/docsSubidos/Boletin-Deuda-Publica/2021/12/01/4_67_0_20211201.PDF (accessed on 1 December 2021).

50. Cámara-Zapata, J.M.; Brotons-Martínez, J.M.; Simón-Grao, S.; Martinez-Nicolás, J.J.; García-Sánchez, F. Cost-benefit analysis of tomato in soilless culture systems with saline water under greenhouse conditions. J. Sci. Food Agric. 2019, 99, 5842-5851. [CrossRef] 